\begin{tabular}{c} 
Tersedia online di: http://ejournal-balitbang.kkp.go.id/index.php/bawal \\
e-mail:bawal.puslitbangkan@ gmail.com \\
BAWAL WIDYA RISET PERIKANAN TANGKAP \\
Volume 10 Nomor 3 Desember 2018 \\
p-ISSN: 1907-8226 \\
e-ISSN: 2502-6410 \\
BAWAL \\
Nomor Akreditasi Kementerian RISTEKDIKTI: 21/E/KPT/2018 \\
\hline \hline
\end{tabular}

\title{
PENGARUH LAMA WAKTU TEBAR PANCING DAN PERENDAMAN TERHADAP HASIL TANGKAPAN ALBAKORA (Thunnus alalunga Bonnaterre, 1788) DI SAMUDRA HINDIA BAGIAN TIMUR
}

\section{EFFECT OF LENGTH OF SETTING AND SOAKING TIME TO THE CATCH OF ALBACORE TUNA (Thunnus alalunga Bonnaterre, 1788) IN EASTERN INDIAN OCEAN}

Irwan Jatmiko*1, Fathur Rochman ${ }^{1}$ dan Zulkarnaen Fahmi ${ }^{1}$

${ }^{1}$ Loka Riset Perikanan Tuna, Jl. Mertasari No.140, Sidakarya, Denpasar Sel., Kota Denpasar, Bali 80224, Indonesia Teregistrasi I tanggal: 03 Nopember 2017; Diterima setelah perbaikan tanggal: 09 Oktober 2018; Disetujui terbit tanggal: 04 Februari 2019

\begin{abstract}
ABSTRAK
Albakora (Thunnus alalunga) merupakan salah satu hasil tangkapan ikan ekonomis penting bagi nelayan rawai tuna di Indonesia. Penelitian ini bertujuan untuk mengetahui pengaruh lama waktu tebar pancing dan perendaman rawai tuna terhadap hasil tangkapan albakora. Pengumpulan data penelitian ini dilakukan oleh observer pada armada rawai tuna yang berfungsi di Samudra Hindia, dilakukan dari bulan Agustus 2005 hingga Agustus 2016. Lama waktu tebar pancing rawai tuna berkisar antara 2-9 jam dengan lama waktu perendaman 114 jam atau rata-rata $5 \mathrm{jam}$. Analisis sidik ragam satu arah menunjukkan bahwa terdapat pengaruh yang nyata pada lama waktu tebar pancing dan perendaman terhadap hasil tangkapan albakora $\left(F_{9,1020}=5,72 ; p<0,05\right)$. Uji Tukey menunjukkan bahwa lama waktu tebar pancing dan perendaman terbaik untuk menangkap albakora adalah masing-masing selama $4 \& 5$ jam dengan rata-rata laju tangkap sebesar 0,37/100 mata pancing. Nelayan armada rawai tuna disarankan untuk mengurangi lama waktu tebar pancing menjadi 4 jam dan tetap mempertahankan lama waktu perendaman 5 jam untuk memperoleh hasil tangkapan albokora secara maksimal.
\end{abstract}

Kata Kunci: Rawai tuna; Thunnus alalunga; Samudra Hindia

\section{ABSTRACT}

Albacore tuna (Thunnus alalunga) is one of the important economic catches for tuna longline fishermen in Indonesia. The objective of this research is to investigate the effect of length of set and soak time of tuna longline vessels to the catch of albacore tuna. The research data was collected by scientific observer on the Indonesian tuna longline vessels and conducted from August 2005 to August 2016. In general, the length of set time on tuna longline vessels ranges from 2-9 hours with the length of soak time from 1-14 hours with average of 5 hours. One way Anova analysis showed that there was a significant difference on the length of set and soak time to the catch of albacore tuna $\left(F_{9,1020}=5,72 ; p<0,05\right)$. Tukey test showed that the best length of set and soak time to catch albacore tuna was 4 \& 5 hours, respectively, with hook rates of 0.37/100 hooks. Fishermen of longline tuna vessels are suggested to reduce the length of set time into 4 hours and to maintain 5 hours of soak time to obtain maximum catch of albacore tuna.

Keywords: Longline tuna; Thunnus alalunga; Indian Ocean

Korespondensi penulis:

e-mail: irwan.jatmiko@gmail.com

Telp. 


\section{PENDAHULUAN}

Albakora (Thunnus alalunga) merupakan salah satu target utama dalam pengkajian karena ikan tuna memiliki nilai ekonomis penting. Di Indonesia, produksi ikan ini mencapai 112 ribu ton dari tahun 2004-2014 atau sekitar 10 ribu ton per tahun (DJPT, 2015). Spesies ini bermigrasi sangat jauh (highly migratory species) di tiga samudra besar dunia yaitu Samudra Hindia, Pasifik dan Atlantik (Childers et al., 2011; Collette et al., 2011; Alonso et al., 2005). Distribusi albakor sangat dipengaruhi oleh kondisi lingkungan seperti suhu permukaan laut dan kelimpahan klorofil-a (Zainuddin et al., 2006).

Albakor di Samudra Hindia banyak ditangkap oleh armada dari negara Taiwan, Jepang dan Korea Selatan (Chen et al., 2004). Jumlah rawai tuna sebesar 98\%, dan sisanya oleh alat tangkap lain seperti pukat cincin (Nishida \& Tanaka, 2008). Secara umum, kondisi stok albakora di Samudra Hindia masih dalam keadaan baik (IOTC, 2016). Meskipun demikian, spesies ini sangat rentan terhadap eksploitasi yang berlebih dikarenakan karakteristik biologi dan siklus hidupnya. Salah satunya karena ikan ini memerlukan waktu yang relatif lama untuk mencapai matang gonad (Nikolic \& Bourjea, 2014). Penelitian oleh Farley et al. (2014) menyatakan bahwa panjang pertama kali matang gonad $(L m)$ albakor adalah $87 \mathrm{cmFL}$ atau berumur 4,5 tahun.

Operasi penangkapan rawai tuna terdiri dari tiga aktivitas utama yaitu tebar pancing (setting), perendaman (soaking) dan tarik pancing (hauling) (Jatmiko et al., 2015). Dari ketiga aktivitas tersebut, aktivitas tebar pancing dan perendaman merupakan faktor yang bisa dikelola oleh kapten kapal. Sementara aktivitas tarik pancing sangat tergantung dengan banyak atau sedikitnya hasil tangkapan ikan. Semakin banyak hasil tangkapan ikan yang diperoleh maka aktivitas tarik pancing akan semakin lama, demikian juga sebaliknya. Beberapa penelitian menyatakan bahwa lama waktu tebar pancing dan perendaman mempengaruhi hasil tangkapan rawai tuna (Setyadji et al., 2016; Triharyuni et al., 2013; Chen et al., 2012). Penelitian ini bertujuan untuk mengetahui pengaruh lama waktu tebar pancing dan perendaman armada rawai tuna terhadap hasil tangkapan albakora di Samudra Hindia bagian timur.

\section{BAHANDANMETODE Pengumpulan Data}

Pengumpulan data penelitian ini dilakukan oleh pemantau ilmiah (scientific observer) pada armada rawai tuna di Samudra Hindia pada bulan Agustus 2005 hingga Agustus 2016. Pemantau ilmiah mencatat beberapa informasi seperti: lama waktu tebar pancing, lama perendaman, jumlah total pancing yang digunakan dan hasil tangkapan albakora. Untuk keperluan analisis, lama waktu tebar pancing dan lama perendaman dikelompokkan setiap satu jam (round down). Sebagai contoh, lama waktu tebar pancing atau lama perendaman selama 3 jam 1 menit dan 3 jam 59 menit akan ditulis sama " 3 jam".

Informasi hasil tangkapan dan jumlah total pancing digunakan untuk menghitung laju tangkap. Nilai laju tangkap diperoleh dengan menghitung proporsi antara hasil tangkapan albakora pada satu operasi tangkapan dibagi total mata pancing yang digunakan pada saat operasi penangkapan tersebut dikalikan 100. Selain itu, pemantau ilmiah juga mencatat posisi daerah penangkapan menggunakan global positioning system (GPS) pada setiap operasi penangkapan dengan ketelitian $1^{\circ}$. Daerah penangkapan armada rawai tuna dalam penelitian ini berada antara $9^{\circ}-15^{\circ} \mathrm{LS}$ hingga $107^{\circ}-121^{\circ}$ BT (Gambar 1). Daerah penangkapan ini masuk dalam Wilayah Pengelolaan Perikanan (WPP) 573.

\section{Analisis Data}

Analisis data penelitian menggunakan sidik ragam satu arah untuk mengetahui pengaruh lama waktu tebar pancing dan perendaman rawai tuna terhadap laju tangkap albakora. Analisis ini digunakan untuk menguji apakah ada perbedaan yang signifikan dari dua/lebih independen variabel terhadap dependen variabel (McDonald, 2014). Independen variabel dalam penelitian ini adalah lama waktu tebar pancing dan lama perendaman rawai tuna. Kedua unsur ini tidak dapat dipisahkan karena lama waktu tebar pancing dan lama perendaman merupakan satu kesatuan dalam operasi penangkapan rawai tuna. Sedangkan dependen variabel dalam penelitian ini adalah nilai laju tangkap yang dihitung dari proporsi jumlah hasil tangkapan albakora dan jumlah total pancing dalam setiap operasi penangkapan. Faktor-faktor lain seperti waktu, titik penangkapan, keahlian kapten dan lain-lain diasumsikan sama dan tidak dimasukkan dalam penghitungan analisis. 


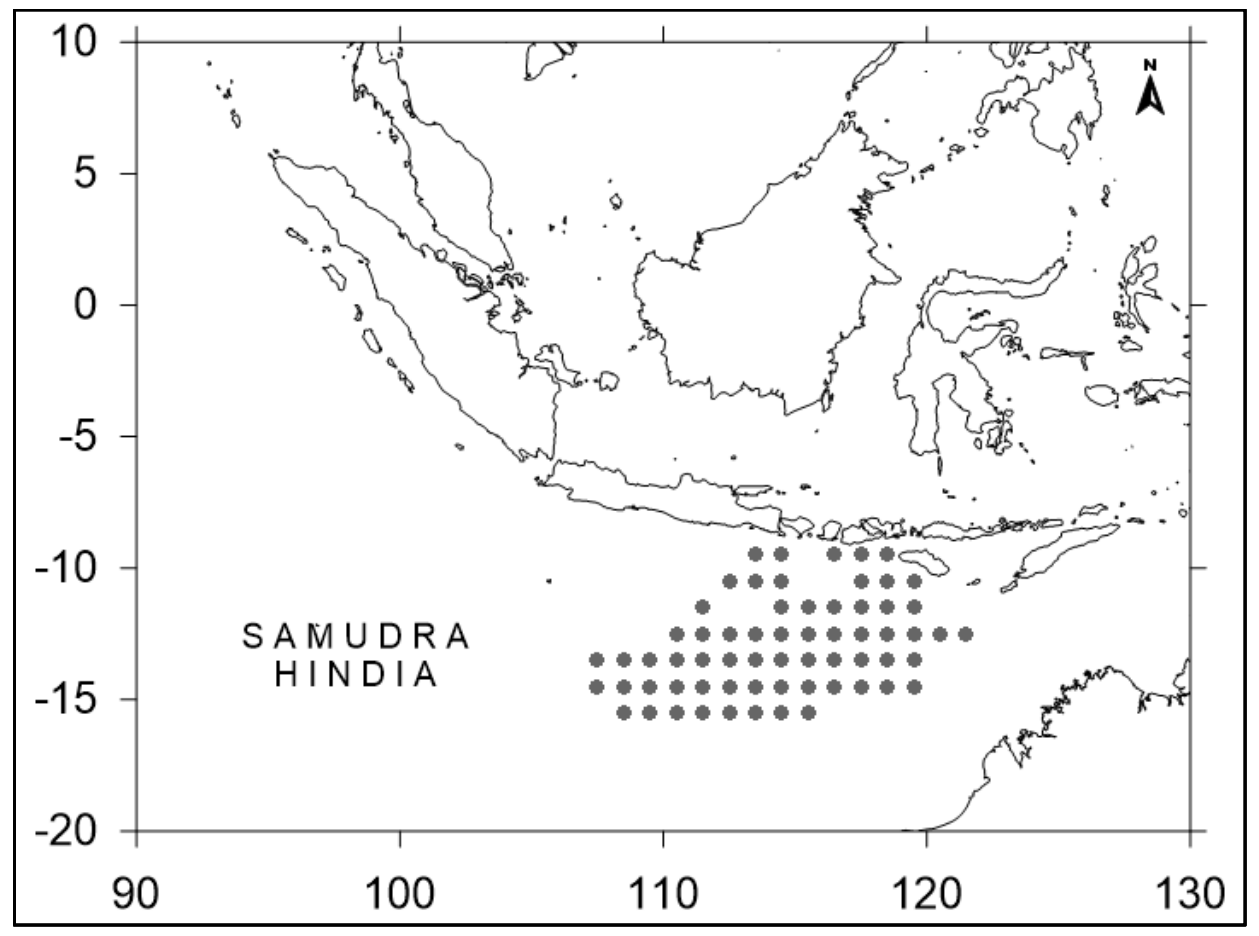

Gambar 1. Daerah penangkapan ikan albakora di Samudera Hindia bagian timur.

Figure 1. Fishing ground of albacore tuna is eastern of Indian Ocean.

Analisis sidik ragam satu arah hanya dilakukan terhadap sepuluh (10) frekuensi tertinggi dari lama waktu tebar pancing dan perendaman. Hal ini dilakukan untuk mewakili lama waktu tebar pancing dan lama waktu perendaman yang sering digunakan oleh armada rawai tuna. Hipotesis yang digunakan dalam penelitian ini adalah:

$H_{0}$ : Tidak ada pengaruh lama waktu tebar pancing dan perendaman rawai tuna terhadap laju tangkap albakora.

$H_{a}$ : Ada pengaruh lama waktu tebar pancing dan perendaman rawai tuna terhadap laju tangkap albakora.

Apabila analisis sidik ragam satu arah menunjukkan perbedaan yang nyata $(p<0,05)$, analisis dilanjutkan dengan melakukan uji Tukey untuk mengetahui letak perbedaan dari variabel tertentu dibandingkan dengan variabel lainnya. Seluruh analisis dalam penelitian ini dilakukan dengan menggunakan SPSS Statistics 20.

\section{HASIL DAN BAHASAN}

Hasil

Penelitian ini berhasil mengumpulkan data dari 70 trip armada rawai tuna dengan jumlah hari operasi sebanyak 1.713 kali. Rata-rata lama waktu tebar pancing dan perendaman pada armada rawai tuna masing-masing selama 5 jam. Rata-rata total pancing yang digunakan dalam sekali operasi penangkapan sebanyak 1.203 mata pancing (Tabel 1). Nilai ini menunjukkan bahwa rata-rata sebanyak 4 mata pancing ditebar per menit. Secara umum, lama waktu tebar pancing rawai tuna berkisar dari 2-9 jam dengan lama waktu perendaman 1-14 jam. Lama waktu tebar pancing dan lama perendaman rawai tuna merupakan aktivitas yang tidak dapat dipisahkan, sehingga analisis dalam penelitian ini menggabungkan kedua unsur tersebut. Dari penggabungan ini diperoleh bahwa operasi rawai tuna paling tinggi melakukan tebar pancing dan perendaman selama masing-masing 4 \& 6 jam sebanyak 232 kali. Diikuti dengan melakukan tebar pancing dan perendaman selama 4 \& 4 jam (136 kali), 5 \& 6 jam (104 kali) dan 5 \& 5 jam (103 kali). Lama waktu tebar pancing dan perendaman secara lengkap dapat dilihat pada Gambar 2. Selanjutnya dilakukan analisis sidik ragam satu arah terhadap 10 frekuensi tertinggi dari lama waktu tebar pancing dan perendaman. Jumlah ini diasumsikan dapat mewakili lama waktu tebar pancing dan perendaman yang sering dilakukan oleh nelayan rawai tuna.

Analisis sidik ragam satu arah menunjukkan bahwa terdapat pengaruh yang nyata pada lama waktu tebar pancing dan perendaman terhadap hasil tangkapan albakora $\left(F_{9,1020}=5,72 ; p<0,05\right)$ (Lampiran 1$)$. Selanjutnya, uji Tukey menunjukkan bahwa lama waktu tebar pancing dan perendaman terbaik untuk menangkap albakora adalah masing-masing selama $4 \& 5$ jam dengan rata-rata laju tangkap sebesar 0,37/100 mata pancing. Hasil ini lebih dari 11 kali lipat dari nilai terendah dengan lama waktu tebar 
pancing dan perendaman $4 \& 3$ jam yang hanya memiliki nilai laju tangkap sebesar 0,03/100 mata pancing. Meskipun demikian, hasil tangkapan dari lama waktu tebar pancing dan perendaman terbaik yaitu selama $4 \& 5$ jam ini, secara statistik tidak berbeda nyata dengan waktu tebar pancing dan perendaman selama 4 \& 6 jam, 4 \& 7 jam, 5 \& 4 jam, 5 $\& 5$ jam dan $6 \& 5$ jam (Gambar 3$)$.

Tabel 1. Jumlah trip, hari operasi, lama waktu tebar pancing, lama waktu perendaman dan rata-rata total pancing armada rawai tuna Indonesia

Table 1. Number of trips, fishing days, length of set time, length of soak time and fishing ground and average of total hooks from tuna longline in Indonesia

\begin{tabular}{cccccc}
\hline $\begin{array}{c}\text { Tahun/ } \\
\text { Year }\end{array}$ & $\begin{array}{c}\text { Jumlah } \\
\text { trip/ } \\
\text { Number } \\
\text { of trips }\end{array}$ & $\begin{array}{c}\text { Jumlah hari } \\
\text { operasi/ Number } \\
\text { offishing days }\end{array}$ & $\begin{array}{c}\text { Lama waktu tebar } \\
\text { pancing rata-rata } \\
\text { (jam)/ Average } \\
\text { length of set time }\end{array}$ & $\begin{array}{c}\text { Lama waktu } \\
\text { perendaman rata-rata } \\
\text { (jam)/ Average length } \\
\text { of soak time (hours) }\end{array}$ & $\begin{array}{c}\text { Total pancing } \\
\text { rata-rata/ } \\
\text { Average of } \\
\text { total hooks }\end{array}$ \\
\hline 2005 & 8 & 79 & 4 & 3 & 1.454 \\
2006 & 9 & 205 & 5 & 5 & 1.424 \\
2007 & 8 & 130 & 4 & 3 & 1.311 \\
2008 & 8 & 276 & 4 & 4 & 1.098 \\
2009 & 9 & 217 & 4 & 5 & 1.149 \\
2010 & 5 & 150 & 4 & 5 & 1.378 \\
2011 & 4 & 108 & 3 & 6 & 1.043 \\
2012 & 4 & 81 & 4 & 5 & 1.026 \\
2013 & 6 & 189 & 4 & 5 & 1.079 \\
2014 & 5 & 151 & 4 & 7 & 1.171 \\
2015 & 3 & 106 & 5 & 6 & 1.217 \\
2016 & 1 & 21 & 5 & 5 & 1.086 \\
\hline
\end{tabular}

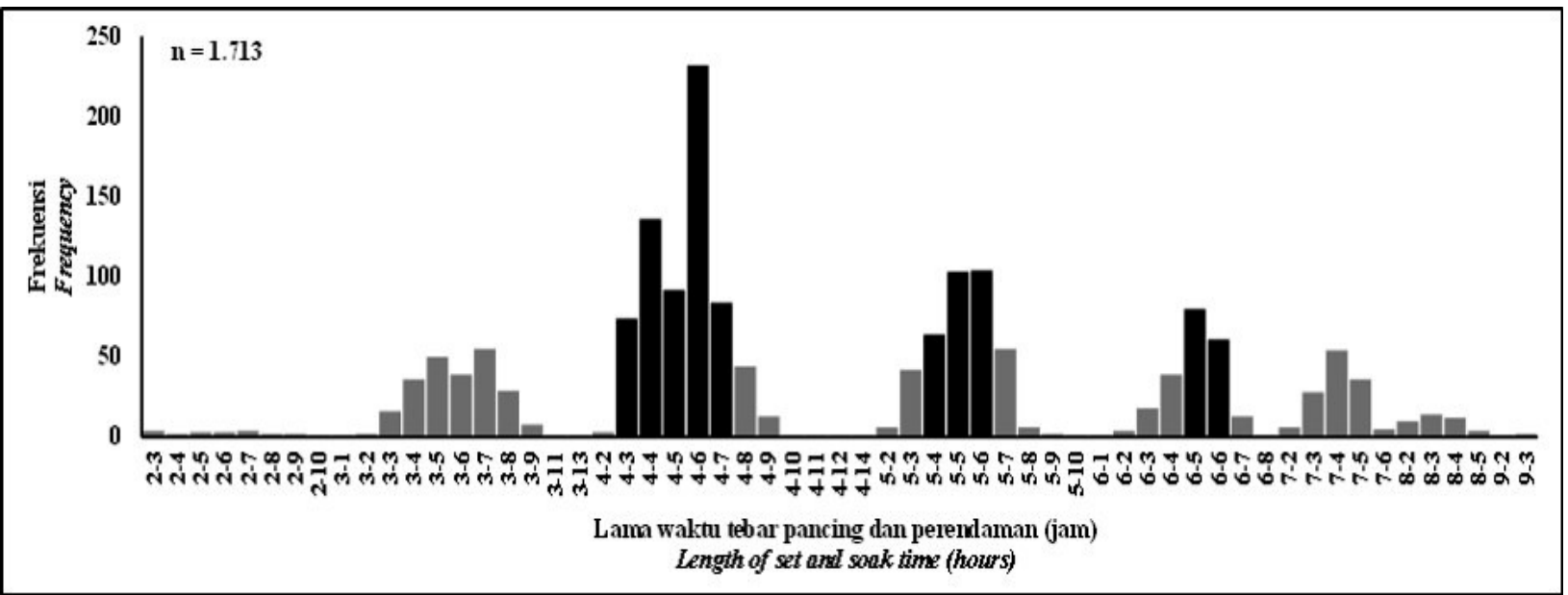

Gambar2. Frekuensi lama waktu tebar pancing dan perendaman rawai tuna Indonesia. Lama waktu tebar pancing ditunjukkan dengan angka pertama dan lama perendaman ditunjukkan dengan angka kedua. Batang berwarna hitam merupakan data yang digunakan untuk analisis sidik ragam satu arah.

Figure 2. Frequency of setting and soak time of tuna longline in Indonesia. Length of set time indicates with first number and length of soak time indicate with second number. Bar with the black colour was used for analysis of one-way Anova. 


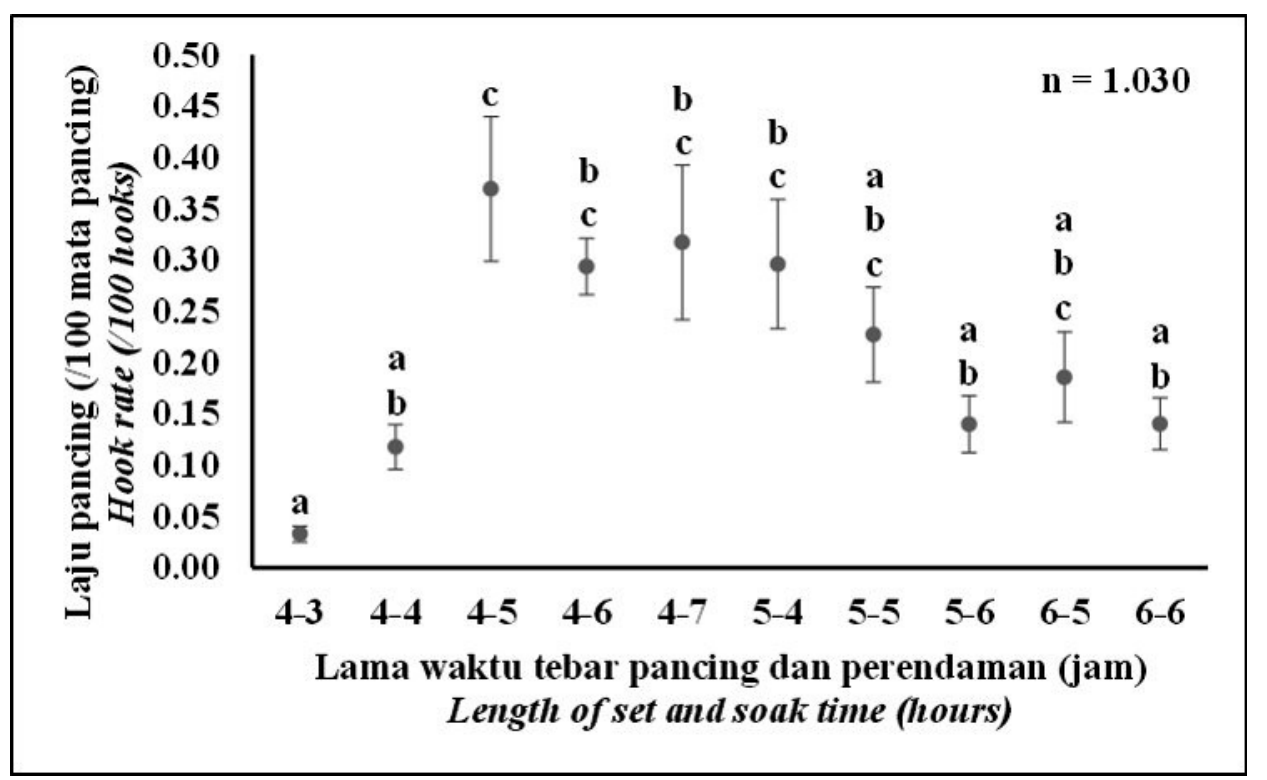

Gambar 3. Laju tangkap albakora (T. alalunga) dari lama waktu tebar pancing dan perendaman rawai tuna. Lama waktu tebar pancing ditunjukkan dengan angka pertama dan lama perendaman ditunjukkan dengan angka kedua. Nilai laju tangkap merupakan rata-rata \pm se. Huruf yang berbeda menunjukkan perbedaan yang signifikan $(p<0,05)$.

Figure 3. Hook rate of tuna albacore (T. alalunga) from setting and soak time of tuna longline. Length of set time indicates with first number and length of soak time indicate with second number. Hook rate value is average \pm se. Different letter showed significantly different $(p<0.05)$.

\section{Bahasan}

Albakora yang tertangkap dalam penelitian ini tersebar dari posisi geografis antara $9-15^{\circ} \mathrm{LS}$ dan $107-121^{\circ} \mathrm{BT}$. Lokasi ini berada di Samudra Hindia sebelah selatan Jawa, Bali dan Nusa Tenggara atau berada di WPP 573. Di Samudra Hindia, spesies ini memiliki daerah penyebaran dari $5^{\circ} \mathrm{LU}$ hingga $40^{\circ} \mathrm{LS}$ (Chen et al., 2004). Informasi tentang daerah penyebaran spesies ikan sangat penting dalam pengelolaan perikanan, salah satunya adalah pendugaan stok spesies ikan di suatu perairan beserta alternatif pengelolaannya (King, 2010; Lehodey, 2001).

Secara umum, aktivitas tebar pancing armada rawai tuna Indonesia dilakukan pagi hari dimulai dari pukul 5:00 - 9:00 (Jatmiko et al., 2016). Dalam penelitian ini diketahui bahwa lama waktu tebar pancing rawai tuna berkisar dari 2-9 jam dengan lama waktu perendaman dari selama 1-14 jam. Durasi ini relatif lebih singkat daripada lama waktu perendaman armada rawai tuna di China yaitu selama 4-22 jam (Chen et al., 2012).

Penelitian ini menggabungkan antara aktivitas lama waktu tebar pancing dan aktivitas lama perendaman karena keduanya merupakan aktivitas yang tidak dapat dipisahkan. Hal ini berbeda dari penelitian Setyadji et al. (2016) yang memisahkan antara lama waktu tebar pancing dan perendaman. Penelitian ini juga berbeda dengan penelitian Triharyuni et al. (2013) yang hanya menganalisis lama waktu tebar pancing maupun penelitian Chen et al. (2012) yang hanya menganalisis lama waktu perendaman.

Hasil dari penelitian ini menunjukkan bahwa lama waktu tebar pancing dan perendaman mempengaruhi hasil tangkapan albakor. Hal ini berbeda dengan penelitian yang dilakukan Setyadji et al. (2016) dan Triharyuni et al. (2013) terhadap spesies madidihang dan tuna mata besar yang menyatakan bahwa tidak terdapat pengaruh yang signifikan dari lama waktu tebar pancing. Namun penelitian Setyadji et al. (2016) menyatakan bahwa terdapat pengaruh yang signifikan dari lama waktu perendaman.

Lama waktu tebar pancing dan perendaman yang dibutuhkan untuk mendapatkan hasil tangkapan albakora secara maksimal adalah selama masing-masing $4 \& 5$ jam. Hal ini berbeda dengan penelitian Chen et al. (2012) yang menyatakan bahwa lama waktu perendaman terbaik adalah 10-12 jam untuk spesies madidihang dan tuna mata besar.

Meskipun demikian, durasi waktu perendaman yang terlalu lama dapat mempengaruhi kualitas daging ikan yang tertangkap. Kualitas ikan yang jelek akan merugikan secara ekonomis menyebabkan harga jual ikan tersebut menjadi rendah. Selain itu, waktu perendaman yang terlalu lama juga dapat meningkatkan risiko ikan yang tertangkap menjadi rusak maupun hilang karena dimakan oleh predator seperti hiu maupun paus (Ward et al., 2004). 
Masalah ini dapat diminimalisir dengan melakukan teknik tarik pancing secara terbalik (backward hauling). Teknik tarik pancing secara terbalik berarti melakukan tarik pancing dimulai dari pancing pertama (pancing yang pertama kali ditebar). Kelebihan dari teknik ini adalah lama waktu perendaman masing-masing mata pancing relatif sama. Sehingga meminimalisir ikan yang tertangkap berada di air dalam waktu yang lama sehingga dapat menjaga kualitas ikan tersebut (Beverly et al., 2003).
Armada rawai tuna Indonesia melakukan aktivitas tebar pancing rata-rata selama 5 jam dengan kisaran 2-9 jam. Meskipun demikian, aktivitas tebar pancing yang paling sering dilakukan adalah selama 4 jam sebanyak $682 \mathrm{kali}$ dengan rata-rata jumlah total mata pancing sebanyak 1.148 buah (Tabel 2). Hal ini sesuai dengan hasil analisis dari penelitian ini yang menyatakan bahwa lama waktu terbaik untuk mendapatkan hasil tangkapan albakora secara maksimal adalah selama 4 jam.

Tabel 2. Jumlah mata pancing menurut lama waktu tebar pancing (jam)

Table 2. Number of hooks by setting time (hours)

\begin{tabular}{|c|c|c|c|c|}
\hline \multirow{2}{*}{$\begin{array}{c}\text { Lama waktu tebar } \\
\text { pancing (jam) }\end{array}$} & \multirow{2}{*}{$\mathrm{n}$} & \multicolumn{3}{|c|}{ Jumlah total mata pancing } \\
\hline & & $\min$ & $\max$ & rata-rata $+/-$ se \\
\hline \multirow{2}{*}{$\begin{array}{l}\text { Length of set } \\
\text { time (hours) }\end{array}$} & \multirow{2}{*}{$n$} & \multicolumn{3}{|c|}{ Total hooks } \\
\hline & & $\min$ & $\max$ & average $+/$-se \\
\hline 2 & 21 & 576 & 1440 & $816 \pm 48$ \\
\hline 3 & 238 & 528 & 2037 & $1080 \pm 18$ \\
\hline 4 & 682 & 596 & 2100 & $1148 \pm 8$ \\
\hline 5 & 383 & 596 & 2058 & $1311 \pm 16$ \\
\hline 6 & 217 & 716 & 2100 & $1350 \pm 17$ \\
\hline 7 & 129 & 796 & 2100 & $1260 \pm 26$ \\
\hline 8 & 40 & 836 & 1782 & $1153 \pm 33$ \\
\hline 9 & 3 & 1056 & 1470 & $1315 \pm 130$ \\
\hline
\end{tabular}

Secara umum, lama waktu tebar pancing berbanding lurus dengan banyaknya total pancing yang ditebar. Semakin lama aktivitas tebar pancing dilakukan, semakin banyak jumlah total mata pancing yang ditebar. Namun hal ini hanya terjadi pada lama waktu tebar pancing 2-6 jam. Sedangkan lama waktu tebar pancing dari 7-9 jam cenderung berfluktuasi terhadap jumlah total pancing yang disebar.

Berdasarkan pengamatan lapang dan wawancara dengan nelayan rawai tuna, fluktuasi total pancing yang ditebar ini terjadi karena teknis operasi penangkapan. Salah satunya disebabkan karena kecepatan kapal pada saat melakukan aktivitas tebar pancing. Semakin cepat melaju akan mengakibatkan jumlah mata pancing yang disebar semakin banyak. Hal lain yang dapat membedakan total pancing yang ditebar adalah adanya kendala teknis pada saat operasi penangkapan seperti putusnya tali utama. Putusnya tali utama mengharuskan kapal untuk mencari pelampung/radio buoy untuk menyambung rangkaian rawai tuna. Aktivitas pencarian ini terkadang memerlukan waktu yang cukup lama. Hal ini menyebabkan bertambahnya durasi waktu tebar pancing namun tidak menambah jumlah mata pancing yang ditebar.

\section{KESIMPULAN}

Operasi penangkapan armada rawai tuna Indonesia secara umum melakukan aktivitas tebar pancing dan perendaman selama masing-masing 5 jam. Meskipun demikian, waktu tebar pancing dan perendaman terbaik untuk menangkap albakora adalah selama 4 jam dengan waktu perendaman selama 5 jam. Oleh karena itu, nelayan armada rawai tuna disarankan untuk mengurangi lama waktu tebar pancing menjadi 4 jam dan tetap mempertahankan lama waktu perendaman 5 jam untuk memperoleh hasil tangkapan albokora secara maksimal. Selain itu, nelayan armada rawai tuna juga disarankan untuk melakukan tarik pancing secara terbalik (backward hauling) untuk menjaga kualitas ikan hasil tangkapan.

\section{PERSANTUNAN}

Penelitian ini dibiayai dari kerjasama Pusat Riset Perikanan (Pusriskan) dengan Australian Centre for International Agricultural Research (ACIAR) pada tahun 2005-2009, DIPA kegiatan riset Balai Riset Perikanan Laut (BRPL) pada tahun 2010-2011 dan DIPA kegiatan riset Loka Riset Perikanan Tuna (LRPT) pada tahun 2012-2016. Peneliti mengucapkan terima kasih kepada para pemantau ilmiah observer di LRPT Benoa yang telah membantu dalam proses pengumpulan data penelitian ini.

\section{DAFTAR PUSTAKA}

Alonso, C.,Arrizabalaga,H., \& Restrepo V.R. (2005). Contribution of a chapter on albacore tuna for the revised ICCAT field manual. Collect Vol Sci Papp ICCAT, 58(5), 1646-1661. 
Beverly, S., Chapman L., \& Sokimi, W. (2003). Horizontal longline fishing methods and techniques: A manual for fishermen (p. 130). Noumea, New Caledonia:Secretariat of the Pacific Community.

Chen, I. C., Lee, P. F., \& Tzeng, W. N. (2004). Distribution of albacore (Thunnus alalunga) in the Indian Ocean and its relation to environmental factors. Fisheries Oceanography, 14(1), 71-80.

Chen, W., Song, L., Li, J., Xu, W., \& Li, D. (2012). Optimum soak time of tuna longline gear in the Indian Ocean. IOTC-2012-WPTT14-11 Rev_2.p. 13.

Childers, J., Snyder, S., \& Kohn, S. (2011). Migration and behavior of juvenile North Paciûc albacore (Thunnus alalunga). Fisheries Oceanography, 20(3), 157-173.

Collette, B. B., Carpenter, K. E., Polidoro, B. A., Juan-Jorda, M. J., \& others. (2011). High value and long life double jeopardy for tunas and billfishes. Science, 333, 291-292.

Direktorat Jenderal Perikanan Tangkap (DJPT). (2015). Statistik Perikanan Tangkap Indonesia Tahun 2014 (p. 427). Jakarta, Indonesia: Direktorat Jenderal Perikanan Tangkap, Kementerian Kelautan dan Perikanan Republik Indonesia.

Farley, J. H., Hoyle, S. D., Eveson, J. P., Williams, A. J., Davies, C. R., \& Nicol, S. J. (2014). Maturity ogives for south pacific albacore tuna (Thunnus alalunga) that account for spatial and seasonal variation in the distributions of mature and immature fish. PLOS ONE, 9(1), e83017.

Indian Ocean Tuna Commission (IOTC). (2016). Report of the sixth session of the IOTC working party on temperate tunas. IOTC-2016-WPTmT06-R[E]. $58 \mathrm{pp}$.

Jatmiko, I., Setyadji, B., \& Wujdi, A. (2016). Pengaruh fase bulan terhadap waktu tebar pancing dan laju tangkap madidihang (Thunnus albacares Bonnaterre, 1788) pada armada rawai tuna. J.Lit.Perikan.Ind, 22(4), 207214.
Jatmiko, I., Nugraha, B., \& Satria, F. (2015). Capaian perkembangan program pemantau pada perikanan rawai tuna di Indonesia. Marine Fisheries, 6(1), 23-31.

King, M. (2010). Fisheries biology, assessment and management, second edition (p. 381). Oxford, England: Blackwell Publising Ltd.

Lehodey, P. (2001). The pelagic ecosystem of the tropical Pacific Ocean: dynamic spatial modelling and biological consequences of ENSO. Progress in Oceanography, 49(1-4), 439-468.

McDonald, J.H. (2014). Handbook of biological statistics, third edition (p. 299). Maryland, USA: Sparky House Publishing.

Nikolic, N., \& Bourjea, J. (2014). Differentiation of albacore stock, review by oceanic regions. Collect. Vol. Sci. Pap. ICCAT, 70(3), 1340-1354.

Nishida, T., \& Tanaka, M. (2008). General review of Indian Ocean albacore (Thunnus alalunga). IOTC-2008WPTe-INFO3.8 pp.

Setyadji, B., Nugraha, B., \& Sadiyah, L. (2016). The effect of depth of hooks, set and soak time to the catch per unit effort of tuna in the Eastern Indian Ocean. Ind.Fis.Res.J, 22(2), 61-68.

Triharyuni, S., Nugraha, B., \& Chodriyah, U. (2013). Pengaruh lama setting dan jumlah pancing terhadap hasil tangkapan rawai tuna di Laut Banda. J.Lit.Perikan.Ind, 19(2), 81-88.

Ward, P., Myers, R. A., \& Blanchard, W. (2004). Fish lost at sea: the effect of soak time on pelagic longline catches. Fishery Bulletin, 102(1), 179-195.

Zainuddin, M., Kiyofuji, H., Saitoh, K., \& Saitoh, S. I. (2006). Using multi-sensor satellite remote sensing and catch data to detect ocean hot spots for albacore (Thunnus alalunga) in the northwestern North Pacific. DeepSea Research II. 53, 419-431. 
Lampiran 1. Hasil analisis sidik ragam satu arah dan uji Tukey menggunakan SPSS Statistics 20.

Appendix 1. Results of one-way Anova analysis and Tukey test using SPSS Statistics 20.

\begin{tabular}{lrrrrr}
\multicolumn{7}{c}{ ANOVA } \\
& \multicolumn{2}{c}{ HRALB } & & \\
& Sum of Squares & df & Mean Square & F & Sig. \\
\hline Between Groups & 9.642 & 9 & 1.071 & 5.720 & .000 \\
Within Groups & 191.030 & 1020 & .187 & & \\
\hline Total & 200.672 & 1029 & & \\
\hline
\end{tabular}

\section{Homogeneous Subsets}

$\underline{\text { Tukey HSD }}{ }^{\mathrm{a}, \mathrm{b}}$

HRALB

\begin{tabular}{|c|c|c|c|c|}
\hline \multirow{2}{*}{ setsoak } & \multirow{2}{*}{$\mathbf{N}$} & \multicolumn{3}{|c|}{ Subset for alpha $=0.05$} \\
\hline & & 1 & 2 & 3 \\
\hline $4-3$ & 74 & .03276405877 & & \\
\hline $4-4$ & 136 & .11758500776 & .11758500776 & \\
\hline $5-6$ & 104 & .13981596614 & .13981596614 & \\
\hline $6-6$ & 61 & .14019024621 & .14019024621 & \\
\hline $6-5$ & 80 & .18570682420 & .18570682420 & .18570682420 \\
\hline $5-5$ & 103 & .22714296267 & .22714296267 & .22714296267 \\
\hline $4-6$ & 232 & & .29352942012 & .29352942012 \\
\hline $5-4$ & 64 & & .29601068903 & .29601068903 \\
\hline $4-7$ & 84 & & .31708115138 & .31708115138 \\
\hline $4-5$ & 92 & & & .36925670978 \\
\hline Sig. & & .081 & .065 & .126 \\
\hline
\end{tabular}

